Ghada Dh Al-Sayagh BDS, MSc (Lect)

\section{The occupational hazards and diseases among dentists in Mosul City: Musculo- skeletal pain, eye problem and hepatitis}

\author{
Dept of Pedod, Orthod and Prev Dent \\ College of Dentistry, University of Mosul
}

\begin{abstract}
Aims: To evaluate the distribution of the health hazards and diseases among dentists in Mosul City according to age, sex and number of working hours per week. It also stated the usage of personal protective measures among dentists. Materials and Methods: The study of population consisted of one hundred and thirty dentists. The target population comprised dentists who worked in Mosul City. The study was conducted within form of questionnaire. Dentists were asked whether they suffered any occupational disease related to a musculo-skeletal pain and its location whether in the back, upper limbs or lower limbs. Also location of back pain as in the neck, shoulder, thoracic, lumber and sacral regions. Additionally, dentists were asked about eye problem, infectious diseases and if they are wearing medical gloves and masks. Results: The musculo-skeletal pain was the most frequent complaint of the total dentists (63.08\%). Back-pain was the most prevalent of the musculo-skeletal disorders among dentists (81.54\%) of the total sample and more frequently in the cervical area; i.e., neck and shoulder (66.15\%). There was a significant difference between the prevalence of different musculo-skeletal pain and the weekly working hours among dentists $(p=0.01)$. There was a significant difference between dentists with and without eye problems $(p=0.033)$. Higher prevalence of dentists from the total sample did not complain of infectious diseases (82.31\%). Dentists whom never wearing gloves and masks comprised the higher percentages of the total sample $(46.15 \%$ and 19.23\%, respectively). Conclusions: Carrying out their professional work, dentists are exposed to a number of occupational hazards. The study revealed that musculo-skeletal pain was the frequent complaint of dentists and more frequently in the cervical area (neck and shoulders) with a significant association between the number of working hours per week and musculo-skeletal pain in all locations (back, upper limb, lower limb). The majority of the examined dentists complain of eye problem during their practice, whereas most of them never complain any infectious disease. No significant association between dentists wearing gloves but significant association between those wearing masks with the age. Key Words: Musculo-skeletal pain, occupational hazards, back pain.
\end{abstract}

Al-Sayagh Gh Dh. The occupational hazards and diseases among dentists in Mosul City: Musculoskeletal pain, eye problem and hepatitis. Al-Rafidain Dent J. 2006; 6(2): 136-143.

Received: 21/11/2005 Sent to Referees: 21/11/2005 Accepted for Publication: 20/12/2005

\section{INTRODUCTION}

Working is the major determinant of our income, style of life, social interaction and health. Our general environment contains many health hazards. During the last 20-30 years, epidemiologists have examined our associations between the risk factors and their effects on our health; one of these factors has been occupation. ${ }^{(1)}$

Occupational safety and health have been a matter for concern since people began working. Dental education has been remiss to adequately preparing dentists and auxiliary personnel to recognize and avoid many of the occupational hazards in the dental environment. ${ }^{(1)}$ During years, there has been an increasing awareness that the dental profession compares unfavourably to certain other occupations in the health and consequently in the sustained productive or earning the capacity of its members, as dentistry characterized by the requirements of sustained concentration of eyes and hands, of working long hours in the same location with a little general muscular activity and few peaks of physical effort. $^{(2)}$

Dentistry has been portrayed as a high-risk profession in a recent reports. A look at several areas of concern, however, 
shows that the field is no more hazardous than any other profession. Health of Dental Health Care Workers (DHCWs) do not seem to be at any significantly higher risk for occupationally acquired diseases when compared with other Health Care Workers (HCWs). Special attention should be paid to DHCWs who are susceptible to disease potentially transmitted in the dental setting. ${ }^{(3)}$

The general practitioners are exposed to a wide diversity of occupational hazards in the practice of their profession. The dental practitioner should be aware of the possible risks associated with the practice of his profession so that the preventive measures can be taken. ${ }^{(4)}$

During most of the dentist's working day, the dentist is sitting or standing for prolonged periods of time. Both positions detracted from the health of the musculoskeletal and circulatory systems. The dentist is often twisted, causing asymmetrical strain or joints and asymmetrical muscle contractions, as well as added wear and tear on the body. ${ }^{(5)}$

A continuous sitting posture that is abnormal can lead to the same spinal problems experienced by the standing dentists. ${ }^{(6)}$

The occupational injuries involve musculo-skeletal tissues that are often related to a repetitive movement, difficult work positions with cervical flexion, rotation adobucted arms, prolonged posture such as sitting and standing activities common in dentistry. So, it is reasonable to suspect that the dentists may be at risk for many musculo-skeletal disorders including neck, shoulders, upper extremities, low back pain and carpal tunnel syndrome, are etiologically related to occupational factors. ${ }^{(7,8)}$

As a result of the increasing presence of viral hepatitis and Human Immune Deficiency Virus (HIV) in the dental patient population, percutaneous injures poses a significant risk to dentist. Anticipation, planning and training can reduce the incidence of injuries and minimize their impact. $^{(9,10)}$

Therefore, this study was conducted to assess the general health and well-being of Iraqi dentists in Mosul City, in addition to the diseases and hazards that affect th- em related to their profession or occupation.

\section{MATERIALS AND METHODS}

The study population consisted of one hundred and thirty dentists. Collection of the data was carried out during the period between the middle of January 2005 until the end of May 2005. Both male and female dentists were included in the study sample.

The target population that will participate in this study comprise dentists who worked in the following centers in the city of Mosul:

1. College of Dentistry.

2. Specialized centers for dental treatment.

3. Private clinics in Mosul City.

The study was conducted in the form of questionnaire, which was given to each dentist and they were asked to answer the questions precisely by putting a signal on the selected square. Personal information were included as age, sex, academic degree BDS, Diploma, MSc, or PhD), number of years practice in clinical dentistry include the two final years of dental studies, and number of working days per week.

Dentists were asked whether they had at any time since starting clinical dentistry suffered from any one of these chronic illnesses and/or occupational diseases which related to musculo-skeletal pain which includes questions about location of musculo-skeletal pain whether in the back, upper limb (hand and arm) or lower limb, which include leg, knee joint and foot. Also location of back pain whether in the neck and shoulders or thoracic or lumber or sacral parts.

Because dentists are exposed to blood and saliva during clinical work, they may be affected by many of contagious diseases so that transmitted from patient, they are asked about hepatitis or other infectious diseases and whether dentists vaccinated against viral hepatitis.

Dentists are exposed to many traumatic injuries while they practice the work by a tool and instruments. So they were asked whether they exposed to any traumatic injury and its location (hand, face and eye).

Dentists asked about usage of preven- 
tive measures during practice of the job. They asked about wearing of protective medical gloves and medical masks during practice of clinical field.

Regarding statistical analysis, data were translated into codes using a specially designed coding sheet, and then entered into a computer system. Statistical analysis of the data in this study included Kolmogorov-Smirnov Test. ${ }^{(11)}$

\section{RESULTS}

One hundred and thirty dentists were represented the sample of the present stu- dy of whom 56.15\% were males and $43.85 \%$ were females. The sample was divided into three age groups as shown in Table (1).

The prevalence of musculo-skeletal pain was shown in Table (2) according to the age groups. The higher prevalence of the selected sample of dentists having musculo-skeletal pain (92.31\%). Statistically, there was significant difference in the prevalence of musculo-skeletal pain between age group $(p=0.04)$.

Table (1): Distribution of dentists according to age and sex

\begin{tabular}{|c|c|c|c|c|c|c|c|}
\hline \multirow{2}{*}{\multicolumn{2}{|c|}{ Age (Years) }} & \multicolumn{2}{|c|}{ Males } & \multicolumn{2}{|c|}{ Females } & \multicolumn{2}{|c|}{ Total } \\
\hline & & No. & $\%$ & No. & $\%$ & No. & $\%$ \\
\hline$<30$ & $\begin{array}{c}\text { No. } \\
\%\end{array}$ & $\begin{array}{c}22 \\
30.14 \\
\end{array}$ & 57.89 & $\begin{array}{c}16 \\
28.07\end{array}$ & 42.11 & $\begin{array}{c}38 \\
29.23\end{array}$ & 100 \\
\hline 30-39 & $\begin{array}{c}\text { No. } \\
\%\end{array}$ & $\begin{array}{c}44 \\
60.27\end{array}$ & 53.66 & $\begin{array}{c}38 \\
66.67\end{array}$ & 46.34 & $\begin{array}{c}82 \\
63.08\end{array}$ & 100 \\
\hline $40-49$ & $\begin{array}{c}\text { No. } \\
\%\end{array}$ & $\begin{array}{c}7 \\
9.59\end{array}$ & 70.0 & $\begin{array}{c}3 \\
5.26\end{array}$ & 30.0 & $\begin{array}{c}10 \\
7.69\end{array}$ & 100 \\
\hline Total & $\begin{array}{c}\text { No. } \\
\%\end{array}$ & $\begin{array}{c}73 \\
100\end{array}$ & 56.15 & $\begin{array}{c}57 \\
100\end{array}$ & 43.85 & $\begin{array}{l}130 \\
100\end{array}$ & 100 \\
\hline
\end{tabular}

Table (2): Prevalence of musculo-skeletal pain among dentists with age

\begin{tabular}{|c|c|c|c|c|c|c|c|}
\hline \multirow{2}{*}{\multicolumn{2}{|c|}{ Age (Years) }} & \multicolumn{2}{|c|}{ Yes } & \multicolumn{2}{|c|}{ No } & \multicolumn{2}{|c|}{ Total } \\
\hline & & No. & $\%$ & No. & $\%$ & No. & $\%$ \\
\hline \multirow{2}{*}{$<30$} & No. & 33 & \multirow{2}{*}{86.84} & 5 & \multirow{2}{*}{13.16} & 38 & \multirow{2}{*}{100} \\
\hline & $\%$ & 27.5 & & 50.0 & & 29.23 & \\
\hline \multirow{2}{*}{$30-39$} & No. & 78 & \multirow{2}{*}{95.12} & 4 & \multirow{2}{*}{4.88} & 82 & \multirow{2}{*}{100} \\
\hline & $\%$ & 65.0 & & 40.0 & & 63.08 & \\
\hline \multirow{2}{*}{ 40-49 } & No. & 9 & \multirow{2}{*}{90.0} & 1 & \multirow{2}{*}{10.0} & 10 & \multirow{2}{*}{100} \\
\hline & $\%$ & 7.5 & & 10.0 & & 7.69 & \\
\hline \multirow{2}{*}{ Total } & No. & 120 & \multirow{2}{*}{92.31} & 10 & \multirow{2}{*}{7.69} & 130 & \multirow{2}{*}{100} \\
\hline & $\%$ & 100 & & 100 & & 100 & \\
\hline
\end{tabular}

As shown in Table (3), the prevalence of back pain was recorded to be higher (66.04\%) in the age group 30-39 years. For upper limb pain, the higher percentage (70\%) recorded with first age group. For lower limb pain the higher percentage (50\%) represented with second age group. The study revealed that there was a statistical significant difference between the pre- valence of different musculo-skeletal pain and the age among dentists $(p=0.04)$; whereas no significant difference was found between sex and the prevalence of musculo-skeletal pain among dentists ( $p=$ 0.065 ). Males showed a higher prevalence in back and upper limb pain $(61.32 \%$ and $60 \%$, respectively) than females (38.68\% and $40 \%$, respectively). 
Table (3): Prevalence of different musculo-skeletal pain among dentists

\begin{tabular}{|c|c|c|c|c|c|c|c|c|c|c|}
\hline \multirow{2}{*}{$\begin{array}{c}\text { Age } \\
\text { (Years) }\end{array}$} & \multirow{2}{*}{\multicolumn{2}{|c|}{ Sex }} & \multicolumn{2}{|c|}{ Back Pain } & \multicolumn{2}{|c|}{ Upper Limb } & \multicolumn{2}{|c|}{ Lower Limb } & \multicolumn{2}{|c|}{ Total } \\
\hline & & & No. & $\%$ & No. & $\%$ & No. & $\%$ & No. & $\%$ \\
\hline \multirow{3}{*}{$<30$} & Males & $\begin{array}{c}\text { No. } \\
\%\end{array}$ & $\begin{array}{c}18 \\
27.70\end{array}$ & 62.07 & $\begin{array}{c}11 \\
91.67\end{array}$ & 37.93 & $\begin{array}{c}0 \\
0.0\end{array}$ & 0.0 & $\begin{array}{c}29 \\
36.71 \\
\end{array}$ & 100 \\
\hline & Females & $\begin{array}{c}\text { No. } \\
\%\end{array}$ & $\begin{array}{c}12 \\
29.27\end{array}$ & 75.0 & $\begin{array}{c}3 \\
37.5\end{array}$ & 18.75 & $\begin{array}{c}1 \\
50.0\end{array}$ & 6.25 & $\begin{array}{c}16 \\
31.37\end{array}$ & 100 \\
\hline & Total & $\begin{array}{c}\text { No. } \\
\%\end{array}$ & $\begin{array}{c}30 \\
28.30\end{array}$ & 66.67 & $\begin{array}{c}14 \\
70.0\end{array}$ & 31.11 & $\begin{array}{c}1 \\
25.0\end{array}$ & 2.22 & $\begin{array}{c}45 \\
34.62\end{array}$ & 100 \\
\hline \multirow{3}{*}{ 30-39 } & Males & $\begin{array}{c}\text { No. } \\
\%\end{array}$ & $\begin{array}{c}43 \\
66.15 \\
\end{array}$ & 95.56 & $\begin{array}{c}1 \\
8.33 \\
\end{array}$ & 2.22 & $\begin{array}{c}1 \\
50.0 \\
\end{array}$ & 2.22 & $\begin{array}{c}45 \\
56.96 \\
\end{array}$ & 100 \\
\hline & Females & $\begin{array}{c}\text { No. } \\
\%\end{array}$ & $\begin{array}{c}27 \\
65.85\end{array}$ & 81.82 & $\begin{array}{c}5 \\
62.5\end{array}$ & 15.15 & $\begin{array}{c}1 \\
50.0\end{array}$ & 3.03 & $\begin{array}{c}33 \\
64.71\end{array}$ & 100 \\
\hline & Total & $\begin{array}{c}\text { No. } \\
\%\end{array}$ & $\begin{array}{c}70 \\
66.04\end{array}$ & 89.75 & $\begin{array}{c}6 \\
30.0 \\
\end{array}$ & 7.69 & $\begin{array}{c}2 \\
50.0 \\
\end{array}$ & 2.56 & $\begin{array}{c}78 \\
60.0 \\
\end{array}$ & 100 \\
\hline \multirow{3}{*}{$40-49$} & Males & $\begin{array}{c}\text { No. } \\
\%\end{array}$ & $\begin{array}{c}4 \\
6.15\end{array}$ & 80.0 & $\begin{array}{c}0 \\
0.0\end{array}$ & 0.0 & $\begin{array}{c}1 \\
50.0\end{array}$ & 20.0 & $\begin{array}{c}5 \\
6.33\end{array}$ & 100 \\
\hline & Females & $\begin{array}{c}\text { No. } \\
\%\end{array}$ & $\begin{array}{c}2 \\
4.88\end{array}$ & 100.0 & $\begin{array}{c}0 \\
0.0\end{array}$ & 0.0 & $\begin{array}{c}0 \\
0.0\end{array}$ & 0.0 & $\begin{array}{c}2 \\
3.92\end{array}$ & 100 \\
\hline & Total & $\begin{array}{c}\text { No. } \\
\%\end{array}$ & $\begin{array}{c}6 \\
5.66\end{array}$ & 85.71 & $\begin{array}{c}0 \\
0.0\end{array}$ & 0.0 & $\begin{array}{c}1 \\
25.0\end{array}$ & 14.29 & $\begin{array}{c}7 \\
5.38\end{array}$ & 100 \\
\hline \multicolumn{2}{|c|}{ Total Males } & $\begin{array}{c}\text { No. } \\
\%\end{array}$ & $\begin{array}{c}65 \\
61.32 \\
\end{array}$ & 82.28 & $\begin{array}{c}12 \\
60.0\end{array}$ & 15.19 & $\begin{array}{c}2 \\
50.0 \\
\end{array}$ & 2.53 & $\begin{array}{c}79 \\
60.77 \\
\end{array}$ & 100 \\
\hline \multicolumn{2}{|c|}{ Total Females } & $\begin{array}{c}\text { No. } \\
\%\end{array}$ & $\begin{array}{c}41 \\
38.68\end{array}$ & 80.39 & $\begin{array}{c}8 \\
40.0\end{array}$ & 15.69 & $\begin{array}{c}2 \\
50.0\end{array}$ & 3.92 & $\begin{array}{c}51 \\
39.23\end{array}$ & 100 \\
\hline \multicolumn{2}{|c|}{ Total } & $\begin{array}{c}\text { No. } \\
\%\end{array}$ & $\begin{array}{c}106 \\
100\end{array}$ & 81.54 & $\begin{array}{r}20 \\
100\end{array}$ & 15.38 & $\begin{array}{c}4 \\
100\end{array}$ & 3.08 & $\begin{array}{c}130 \\
100\end{array}$ & 100 \\
\hline \multicolumn{3}{|c|}{ Kolomogorov-Smirnov T } & $\begin{array}{l}\text { For age: } \\
\text { For sex: }\end{array}$ & $\begin{array}{l}=0.286 \\
=0.313\end{array}$ & $\begin{array}{l}p=0.0 \\
p=0.0\end{array}$ & & $\begin{array}{l}\text { ignific } \\
\text { Not Si }\end{array}$ & cant & & \\
\hline
\end{tabular}

Table (4) displayed statistically a significant difference between different musculo-skeletal pain and weekly working hours among dentists $(p=0.01)$. Dentists working from 5-10 hours weekly showed the higher prevalence in different locations in the back, upper limb and lower limb (54.72\%, $40 \%$ and $50 \%$ respectively).
Table (5) showed a significant difference between the prevalence of different types of back pain and the age $(p=0.01)$. The second age group reported a higher prevalence in the neck and shoulder, then lumber and finally sacral area $(69.77 \%$, $57.14 \%$ and $50 \%$ respectively).

Table (4): Prevalence of different musculo-skeletal pain by weekly working hours among dentists

\begin{tabular}{|c|c|c|c|c|c|c|c|c|c|}
\hline \multirow{2}{*}{\multicolumn{2}{|c|}{$\begin{array}{c}\text { Weekly } \\
\text { Working } \\
\text { Hours }\end{array}$}} & \multicolumn{2}{|c|}{ Back Pain } & \multicolumn{2}{|c|}{ Upper Limb } & \multicolumn{2}{|c|}{ Lower Limb } & \multicolumn{2}{|c|}{ Total } \\
\hline & & No. & $\%$ & No. & $\%$ & No. & $\%$ & No. & $\%$ \\
\hline$<5$ & $\begin{array}{c}\text { No. } \\
\%\end{array}$ & $\begin{array}{c}46 \\
43.40 \\
\end{array}$ & 76.67 & $\begin{array}{c}12 \\
60.0 \\
\end{array}$ & 20.0 & $\begin{array}{c}2 \\
50.0 \\
\end{array}$ & 3.33 & $\begin{array}{c}60 \\
46.15 \\
\end{array}$ & 100 \\
\hline 5-10 & $\begin{array}{c}\text { No. } \\
\%\end{array}$ & $\begin{array}{c}58 \\
54.72 \\
\end{array}$ & 85.29 & $\begin{array}{c}8 \\
40.0 \\
\end{array}$ & 11.77 & $\begin{array}{c}2 \\
50.0 \\
\end{array}$ & 2.94 & $\begin{array}{c}68 \\
52.31 \\
\end{array}$ & 100 \\
\hline$>10$ & $\begin{array}{c}\text { No. } \\
\%\end{array}$ & $\begin{array}{c}2 \\
1.88 \\
\end{array}$ & 100.0 & $\begin{array}{c}0 \\
0.0 \\
\end{array}$ & 0.0 & $\begin{array}{c}0 \\
0.0 \\
\end{array}$ & 0.0 & $\begin{array}{c}2 \\
1.54 \\
\end{array}$ & 100 \\
\hline Total & $\begin{array}{c}\text { No. } \\
\%\end{array}$ & $\begin{array}{l}106 \\
100 \\
\end{array}$ & 81.54 & $\begin{array}{c}20 \\
100 \\
\end{array}$ & 15.38 & $\begin{array}{c}4 \\
100 \\
\end{array}$ & 3.08 & $\begin{array}{l}130 \\
100 \\
\end{array}$ & 100 \\
\hline
\end{tabular}

Kolomogorov-Smirnov Test: $\mathrm{D}=0.322 \quad p=0.01 \quad$ Significant 
Table (5): Prevalence of different types of back pain by age

\begin{tabular}{|c|c|c|c|c|c|c|c|c|c|c|c|}
\hline \multirow{2}{*}{\multicolumn{2}{|c|}{ Age (Years) }} & \multicolumn{2}{|c|}{$\begin{array}{l}\text { Neck and } \\
\text { Shoulder }\end{array}$} & \multicolumn{2}{|c|}{ Chest } & \multicolumn{2}{|c|}{ Lumber } & \multicolumn{2}{|c|}{ Sacral } & \multicolumn{2}{|c|}{ Total } \\
\hline & & No. & $\%$ & No. & $\%$ & No. & $\%$ & No. & $\%$ & No. & $\%$ \\
\hline$<30$ & $\begin{array}{c}\text { No. } \\
\%\end{array}$ & $\begin{array}{c}20 \\
23.26\end{array}$ & 52.63 & $\begin{array}{c}4 \\
100.0\end{array}$ & 10.53 & $\begin{array}{c}9 \\
32.14\end{array}$ & 23.68 & $\begin{array}{c}5 \\
41.67\end{array}$ & 13.16 & $\begin{array}{c}38 \\
29.23\end{array}$ & 100 \\
\hline 30-39 & $\begin{array}{l}\text { No. } \\
\%\end{array}$ & $\begin{array}{c}60 \\
69.77\end{array}$ & 73.17 & $\begin{array}{c}0 \\
0.0\end{array}$ & 0.0 & $\begin{array}{c}16 \\
57.14\end{array}$ & 19.51 & $\begin{array}{c}6 \\
50.0\end{array}$ & 7.32 & $\begin{array}{c}82 \\
63.08\end{array}$ & 100 \\
\hline $40-49$ & $\begin{array}{c}\text { No. } \\
\%\end{array}$ & $\begin{array}{c}6 \\
6.97\end{array}$ & 60.0 & $\begin{array}{c}0 \\
0.0\end{array}$ & 0.0 & $\begin{array}{c}3 \\
10.72\end{array}$ & 30.0 & $\begin{array}{c}1 \\
8.33\end{array}$ & 10.0 & $\begin{array}{c}10 \\
7.69\end{array}$ & 100 \\
\hline Total & $\begin{array}{c}\text { No. } \\
\%\end{array}$ & $\begin{array}{c}86 \\
100 \\
\end{array}$ & 66.15 & $\begin{array}{c}4 \\
100\end{array}$ & 3.08 & $\begin{array}{c}28 \\
100\end{array}$ & 21.54 & $\begin{array}{c}12 \\
100\end{array}$ & 9.23 & $\begin{array}{l}130 \\
100\end{array}$ & 100 \\
\hline
\end{tabular}

Kolomogorov-Smirnov Test: $\mathrm{D}=0.294 \quad p=0.01 \quad$ Significant

Table (6) revealed the prevalence of eye problems among dentists according to age. The difference was statistically significant $(p=0.033)$. This study revealed a higher prevalence of eye problems (68.42\%) among the second age.

Table (7) showed the distribution of dentists according to the prevalence of infectious diseases and age. Statistically, no significant difference ( $p=0.15$ ) was found. Dentists with age group 30-39 years comprise the higher prevalence of infectio- us diseases (73.91\%).

Table (8) showed a distributive use of gloves and masks (as protective measures) by dentists according to the age. This study revealed no statistical difference between the prevalence of using protective gloves and significant differences between those wearing masks with the age $(p=0.099$ and 0.01 respectively). Dentists whom never wearing gloves and masks show the higher percentage (46.15\% and $19.23 \%$ respectively).

Table (6): Prevalence of eye problem among dentists according to age

\begin{tabular}{|c|c|c|c|c|c|c|c|}
\hline \multirow{2}{*}{\multicolumn{2}{|c|}{ Age (Years) }} & \multicolumn{2}{|c|}{ Yes } & \multicolumn{2}{|c|}{ No } & \multicolumn{2}{|c|}{ Total } \\
\hline & & No. & $\%$ & No. & $\%$ & No. & $\%$ \\
\hline$<30$ & $\begin{array}{c}\text { No. } \\
\%\end{array}$ & $\begin{array}{c}21 \\
22.11\end{array}$ & 55.26 & $\begin{array}{c}17 \\
48.57\end{array}$ & 44.74 & $\begin{array}{c}38 \\
29.23\end{array}$ & 100 \\
\hline 30-39 & $\begin{array}{c}\text { No. } \\
\%\end{array}$ & $\begin{array}{c}65 \\
68.42\end{array}$ & 79.27 & $\begin{array}{c}17 \\
48.57\end{array}$ & 20.73 & $\begin{array}{c}82 \\
63.08\end{array}$ & 100 \\
\hline $40-49$ & $\begin{array}{c}\text { No. } \\
\%\end{array}$ & $\begin{array}{c}9 \\
9.47\end{array}$ & 90.0 & $\begin{array}{c}1 \\
2.86\end{array}$ & 10.0 & $\begin{array}{c}10 \\
7.69\end{array}$ & 100 \\
\hline Total & $\begin{array}{c}\text { No. } \\
\%\end{array}$ & $\begin{array}{c}95 \\
100 \\
\end{array}$ & 73.08 & $\begin{array}{c}35 \\
100 \\
\end{array}$ & 26.92 & $\begin{array}{l}130 \\
100 \\
\end{array}$ & 100 \\
\hline
\end{tabular}

Kolomogorov-Smirnov Test: $\mathrm{D}=0.345 \quad p=0.033 \quad$ Significant

Table (7): Distribution of dentists according to the prevalence of infectious diseases and age

\begin{tabular}{|c|c|c|c|c|c|c|c|}
\hline \multirow{2}{*}{\multicolumn{2}{|c|}{ Age (Years) }} & \multicolumn{2}{|c|}{ Yes } & \multicolumn{2}{|c|}{ No } & \multicolumn{2}{|c|}{ Total } \\
\hline & & No. & $\%$ & No. & $\%$ & No. & $\%$ \\
\hline$<30$ & $\begin{array}{c}\text { No. } \\
\%\end{array}$ & $\begin{array}{c}4 \\
17.39\end{array}$ & 10.53 & $\begin{array}{c}34 \\
31.78\end{array}$ & 89.47 & $\begin{array}{c}38 \\
29.23\end{array}$ & 100 \\
\hline 30-39 & $\begin{array}{l}\text { No. } \\
\%\end{array}$ & $\begin{array}{c}17 \\
73.91\end{array}$ & 20.73 & $\begin{array}{c}65 \\
60.75\end{array}$ & 79.27 & $\begin{array}{c}82 \\
63.08\end{array}$ & 100 \\
\hline $40-49$ & $\begin{array}{c}\text { No. } \\
\%\end{array}$ & $\begin{array}{c}2 \\
8.70\end{array}$ & 20.0 & $\begin{array}{c}8 \\
7.47\end{array}$ & 80.0 & $\begin{array}{c}10 \\
7.69\end{array}$ & 100 \\
\hline Total & $\begin{array}{c}\text { No. } \\
\%\end{array}$ & $\begin{array}{c}23 \\
100 \\
\end{array}$ & 17.69 & $\begin{array}{l}107 \\
100 \\
\end{array}$ & 82.31 & $\begin{array}{l}130 \\
100 \\
\end{array}$ & 100 \\
\hline
\end{tabular}

Kolomogorov-Smirnov Test: D $=0.243 \quad p=0.15 \quad$ Not Significant 
Table (8): Distribution of the usage of masks and gloves by dentists according to age

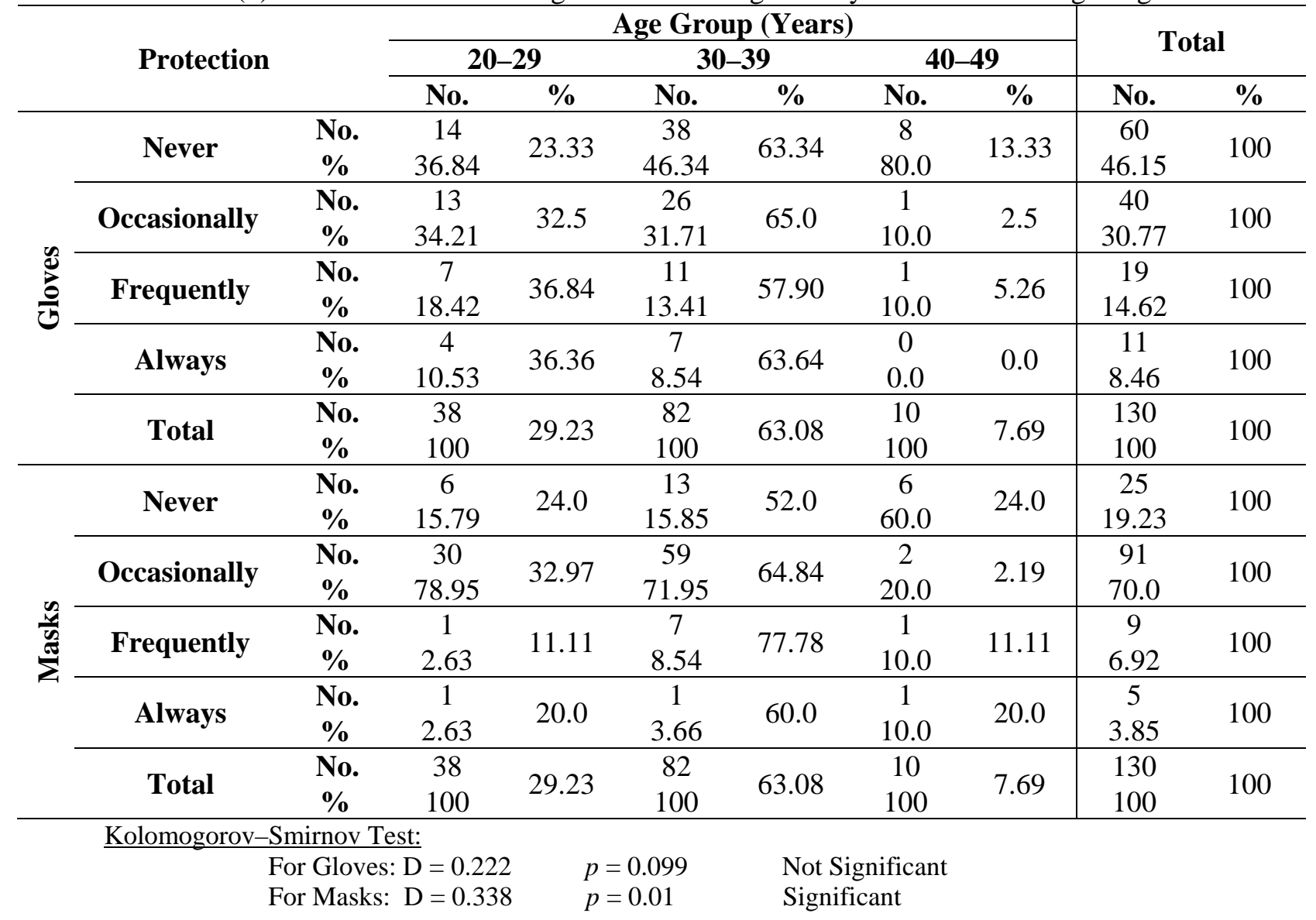

\section{DISCUSSION}

Dentists in the public dental service were found to have a higher prevalence of pain and discomfort in the locomotor system. Personal harmony and age had the highest value, for explaining the number of painful sites in the musculo-skeletal system. ${ }^{(9)}$

An epidemiological survey was studied the prevalence of back pain. A significant number of back pain suffers indicated recurrent or constant pain and many dentists reported practice as an aggravating factor. $^{(12)}$

Musculo-skeletal pain was found to be the most common disorder among dentists in the present study. This finding was in agreement with those of Fish and Morris. ${ }^{(13)}$ This high frequency was probably related to their heavy work with difficult working position, repetitive routine movement and prolonged working hours. This was in agreement with other studies conducted. ${ }^{(14,15)}$

Regarding location of musculo-skele- tal pain, back pain was found to be the most common among dentists (81.54\%). This finding was higher than the result of Edwards. ${ }^{(16)}$ Concerning the location of back pain, it was noticed that the cervical region (neck and shoulder) was the most common (66.15\%). Males affected more than females $(61.32 \%$ and $38.68 \%$ respectively).

The high frequency of symptoms from the neck and shoulders was probably related to their difficult work position with cervical flexion and rotation, in addition to the severe strain on the shoulder girdle through raising the elbows and so raising the shoulders as well. Males affected more than females because a higher percentage of the total sample of the examined dentists was males. These findings were consistent with those of other studies. ${ }^{(2,14,17)}$

However, in this study, neck and shoulder pain show a higher prevalence than chest, lumber and sacral pain. This may be due to the physical fatigue of standing. In addition to that, dentists in sitting or stand- 
ing for a long period of time, both positions detracted from the health of the musculo-skeletal system. This was in accordance with other studies. ${ }^{(6,15,17)}$

Regarding the working hours, this study demonstrated that dentists working 510 hours weekly represent the higher prevalence of musculo-skeletal pain especially in the back area $(54.72 \%)$. This is due to the fact that dentistry is a stressful occupation so dentists practice their job with regard to various health hazards and resultant disabilities. These findings agreed with other studies. ${ }^{(17-19)}$

The present study revealed high prevalence of eye problem among dentists. Second age group represented the higher percentage (68.42\%). This indicated the cumulative hazardous effect of dentistry on the eye. These findings were in agreement with the findings of other studies. ${ }^{(5,6,15,19)}$

The prevalence of infectious diseases in this study was about $17.69 \%$ of the total sample with a higher percentage with second age group (73.91\%). This may be due to that dentists with more years in practice had a higher prevalence of infectious diseases (especially hepatitis). Also the higher percentage of the target population (63.08\%) who are participated in this survey comprise dentists with second age group (30-39 years). This was in accordance with the findings of other studies. ${ }^{(20-25)}$

Concerning usage of protective measures, no significant association was found between dentists wearing gloves but with significant association between those wearing masks with the age. Dentists whom never wearing gloves and masks represent the higher percentages $(46.15 \%$ and $19.23 \%$ ) respectively; whereas according to age, higher prevalence of dentists occasionally wearing masks represent those with second age group (78.95\%). This may be due to that younger age dentists show more awareness about their general health and they concentrate on the use of any type of protective measures like medical masks to avoid any type of occupational hazard and infectious disease especially viral hepatitis. In addition to that, dentists with the second age group (30-39 years) represent the higher percentage of the total sample of the examined dentists (63.08\%). Th- ese findings were in agreement with other studies. ${ }^{(17,26-28)}$

\section{CONCLUSIONS}

Surveys which have been conducted among dental practitioners showed that the chief occupational hazards associated with dentistry are postural defect, eye problem and infectious diseases.

Dentists and dental professionals constitute a sizable occupational group at risk to the multiple exposure. This study revealed that the musculo-skeletal pain was the frequent complaint of dentists and more frequently in the cervical area with a significant association between the working hours per week and musculo-skeletal pain in all locations. The majority of the examined dentists complained of eye problem during their practice, most of them did not complain of any infectious diseases. No significant association between dentists wearing gloves whereas significant association between those wearing masks with the age.

\section{REFERENCES}

1) Goldman HS, Hartman KS, Messite J. Occupational Hazards in Dentistry. Yearbook Medical Publishers Inc. Chicago. 1984; p: 15.

2) Akesson I, Johnsson B, Rylander L, Moritz Uiskerfoing S. Musculo-skeletal disorders among female dental personnel-Clinical examination and a 5year follow up study of symptoms. Int Arch Occup Environ Health. 1999; 72(6): 395-403.

3) Garfunkel AA, Galili D. Dental health care workers at risk. Dent Clin North Am. 1996; 40(2): 277-291.

4) Barnes JB, Harrel SK, Rivera Hidalgo F. Blood contamination of the aerosols produced by in vivo use of ultrasonic scalers. J Periodontol. 1998; 69(4): 434-438.

5) McCarthy GM, Koval JJ, MacDonald JK. Occupational injuries and exposure among Canadian dentists: The result of a national survey. Infect Cont Hosp Epidemiol. 1999; 20(5): 331-334.

6) Warr BG, Fuller SS, Harnerr R, Treasure ET, Scillman-Lowe C. Oral health promotion evaluation-Time for devel- 
opment. Community Dent Oral Epidemiol. 2001; 29: 161-166.

7) Sheiham A. Improving oral health for all focusing on determinants and conditions. Health Educ J. 2000; 59: 351363.

8) Harte J, Davis R, Plamondon T, Richardson $\mathrm{B}$. The influence of dental unit design on percutaneous injury. $\mathrm{J} \mathrm{Am}$ Dent Assoc. 1998; 129: 1725-1731.

9) Koretz RI, Abbey H, Coleman E. NonA, non-B post-transfusion hepatitis looking back on the second decade. Ann Intern Med. 1993; 119: 110-118.

10) Nuttal NM, Steele JG, Pine GM, White D, Pitts NB. The impact of oral health care on people in the UK in 1998. $\mathrm{Br}$ Dent J. 2001; 190: 121-126.

11) Hettmansperger TP, Sheather SJ. Confidence intervals based on interpolated order statistics. Stat Prob Letters. 1986; 4(2): 75-79.

12) Orient JM. Sapira's Art and Science of Bedside Diagnosis. $3^{\text {rd }}$ ed. Lippincott Williams and Wilkins, Philadelphia. 2000; Pp: 42-45.

13) Fish DR, Morris A. Musculo-skeletal disorders in dentists. NY State Dent $J$. 1998; 64(4): 44-48.

14) Milerad E, Ericson MO, Nisell R, Kilborn A. An electromyographic study of dental work. Ergonomics. 1991; 34(7): 953-962.

15) Tosic G. Occupational hazards in dentistry. Part 1: Allergic reactions to dental restoration materials and latex sensitivity. Fact Universitatis Series Working and Living Environmental Protection. 2004; 2(4): 317-324.

16) Edwards SD. Prevention of disability on grounds of suffering. $J$ Med Ethics. 2001; 27: 380-382.

17) Marshall ED, Duncombe M, Robinson RQ, Kilbreath SL. Musculo-skeletal symptoms in New South Wales dentists. Aust Dent J. 1997; 42(4): 240-246.
18) Tilak UW, Pahwa VK. Occupational hazards in medical profession. Med $J$ Armed Forces India. 1993; 49(1): 1-3.

19) Lonnroth EC, Shahnavaz H. Adverse respiratory tract among dental personnel in Sweden. Swed Dent J. 1998; 22(1-2): 33-45.

20) Gillerist JA. Hepatitis viruses A, B, C, D, E and G: Implications for dental personnel. J Am Dent Assoc. 1999; 130: 509-520.

21) Moen RE, Bijorvatn K. Musculo-skeletal symptoms among dentists in a dental school. Occup Med Oxf. 1996; 46(1): 65-68.

22) Christensen H, Finsen L. Musculo-skeletal disorders among dentists and lack of variation in the dental work. Proc $12^{\text {th }}$ Triennial Cong. Int Ergonomics Assoc. 1994; 2: 105-107.

23) Centers for Disease Control and Prevention. World TBG day-March 24, 2001. MMWR Mortal Wkly Rep. 2001; 50: 201.

24) Armstrong GL, Alter MJ, McQuillan GM. The past incidence of hepatitis C virus infection: Implications for the future burden of chronic liver disease in the United States. Hepatol. 2000; 31: 777-783.

25) Centers for Disease Control and Prevention. HIV/AIDS surveillance Report. 2000; $12: 1$.

26) Haider Z. A survey of gloves and masks utilization in a dental school clinic. Med J. 1995; 16(1): 9-12.

27) Al-Taai AA. Occupational hazards and diseases among dentists in Baghdad City. MSc thesis. College of Dentistry. University of Baghdad. 2001.

28) Pretorius E, Bester MJ. What every health worker should know: The allergic potential of surgical gloves. SAfr J Epidemiol Infect. 2000; 15: 43-45. 